\title{
Chemical Diversity and Biological Activities of Marine Sponges of the Genus Suberea: A Systematic Review
}

\author{
Amr El-Demerdash ${ }^{1,2, *(\mathbb{D}}$, Atanas G. Atanasov ${ }^{3,4}{ }^{\circledR}$, Olaf K. Horbanczuk ${ }^{5}$, \\ Mohamed A. Tammam 6,7 (D), Mamdouh Abdel-Mogib ${ }^{2}$, John N. A. Hooper ${ }^{8}$ (D, \\ Nazim Sekeroglu ${ }^{9}$, Ali Al-Mourabit ${ }^{1}$ and Anake Kijjoa ${ }^{10, * \mathbb{D}}$ \\ 1 Institut de Chimie des Substances Naturelles, CNRS UPR 2301, Univ. Paris-Sud, University of Paris-Saclay, 1, \\ Avenue de la Terrasse, 91198 Gif-Sur-Yvette, France; Ali.ALMOURABIT@cnrs.fr \\ 2 Organic Chemistry Division, Chemistry Department, Faculty of Science, Mansoura University, \\ 35516 Mansoura, Egypt; mmdhbdlmgb@gmail.com \\ 3 Department of Pharmacognosy, University of Vienna, 1090 Vienna, Austria; atanas.atanasov@univie.ac.at \\ 4 Institute of Genetics and Animal Breeding of the Polish Academy of Sciences, 05-552 Jastrzebiec, Poland \\ 5 Faculty of Human Nutrition and Consumer Sciences, Warsaw University of Life Sciences, \\ 02-776 Warsaw, Poland; ollafson@onet.pl \\ 6 Department of Pharmacognosy and chemistry of natural products, Faculty of Pharmacy, National and \\ kapodistrian University of Athens, Panepistimiopolis Zografou, 15771 Athens, Greece; \\ mat01@fayoum.edu.eg \\ 7 Department of Biochemistry, Faculty of Agriculture, Fayoum University, 63514 Fayoum, Egypt \\ 8 Queensland Museum, P.O. Box 3300, South Brisbane BC, QLD 4101, Australia; john.hooper@qm.qld.gov.au \\ 9 Department of Food Engineering, Faculty of Engineering and Architecture, Killis 7 Aralik University, \\ 79000 Kilis, Turkey; nsekeroglu@gmail.com \\ 10 ICBAS-Instituto de Ciências Biomédicas Abel Salazar \& CIIMAR, Universidade do Porto, Rua de Jorge \\ Viterbo Ferreira, 228, 4050-313 Porto, Portugal \\ * Correspondence: eldemerdash555@gmail.com (A.E.-D.); ankijjoa@icbas.up.pt (A.K.); \\ Tel.: +33-758-490-229 (A.E.-D.); +351-220-428-331 (A.K.)
}

Received: 16 January 2019; Accepted: 11 February 2019; Published: 12 February 2019

\begin{abstract}
Marine natural products (MNPs) continue to be in the spotlight in the global drug discovery endeavor. Currently, more than 30,000 structurally diverse secondary metabolites from marine sources have been isolated, making MNPs a profound, renewable source to investigate novel drug compounds. Marine sponges of the genus Suberea (family: Aplysinellidae) are recognized as producers of bromotyrosine derivatives, which are considered distinct chemotaxonomic markers for the marine sponges belonging to the order Verongida. This class of compounds exhibits structural diversity, ranging from simple monomeric molecules to more complex molecular scaffolds, displaying a myriad of biological and pharmacological potentialities. In this review, a comprehensive literature survey covering the period of 1998-2018, focusing on the chemistry and biological/pharmacological activities of marine natural products from marine sponges of the genus Suberea, with special attention to the biogenesis of the different skeletons of halogenated compounds, is presented.
\end{abstract}

Keywords: marine sponges; Verongida; Suberea; bromotyrosine derivatives; bioactivities; biosynthesis

\section{Introduction}

Oceans occupy almost $70 \%$ of the Earth's surface, furnishing extraordinary biological and chemical diversity in different ecosystems on our planet [1]. Marine natural products (MNPs) have displayed a distinct track record as a rich and renewable source for novel drug leads [2]. Indeed, the majority of the 
newly discovered pharmacophores with potent biological/pharmacological activities are derived from marine sponges, corals, and tunicates, among other marine invertebrates [3]. Marine sponges (phylum: Porifera) are a large phylum within the animal Kingdom, and are considered prolific factories for producing bioactive natural products [4-7]. Currently, many MNPs and their derivatives are among the approved drugs on the market. These include anticancer drugs such as cytarabine (Cytosar-Uß, DepoCyst ${ }^{\circledR}:$ FDA approval in 1969 for cancer), vidarabine (Vira-A ${ }^{\circledR}$, approved by FDA in 1976 as an antiviral), trabectedin (Yondelis ${ }^{\circledR}$, ET- 743, EU approval in 2011 for cancer), eribulin mesylate (Halaven ${ }^{\circledR}$, FDA approval in 2010, and Heath Canada approval in 2011 for metastatic breast cancer), and brentuximab vidotin (Adcetris ${ }^{\circledR}$, FDA approval in 2011 for Hodgkin's lymphoma and in 2017 for cutaneous T-cell lymphoma), and other drugs such as ziconotide (Prialt®, approved by FDA in in 2004 as an analgesic for treatment of severe chronic pain) and $\omega-3$ acid ethyl esters (Lovaza ${ }^{\circledR}$, approved by FDA in 2004 for lowering blood triglyceride levels in adults with severe hypertriglyceridemia) [8-10]. Furthermore, more than twelve marine-derived compounds are currently under investigation in different clinical phases [2,8-10].

Suberea Bergquist, 1995 [11] is a genus of keratose (or horny) sponges that lacks a mineral skeleton, belonging to the Order Verongida (Family: Aplysinellidae). Species of Suberea have smooth or conulose surfaces and can be massive, stalked, or have branching growth forms. Their live coloration is usually bright and vivid (e.g., yellow, orange, brown, or red), with aerophobic pigments that darken when exposed to air. They have thick spongin fibers that form an irregular dendritic skeleton composed of both bark (external) and pith (central) fiber components, with the latter predominating. The bark component of the fibers is strongly laminated, which makes the fibers brittle. In addition, a dense, collagenous mesohyle between the fibers makes these sponges hard and barely compressible [11,12]. The World Porifera Database indicated that the genus Suberea currently contains 14 described species within Suberea Bergquist, 1995, including: S. azteca [13]; S. clavata [14]; S. creba [11]; S. elegans [15]; S. etiennei van Soest, Kaiser \& Van Syoc, 2011 [16]; S. flavolivescens [17]; S. fusca [18]; S. ianthelliformis [15]; S. laboutei Bergquist [11]; S. meandrina [19]; S. mollis [20]; S. pedunculata [21]; S. praetensa [20]; and S. purpureaflava Gugel, Wagler \& Brümmer, 2011 [22]. Sponges of the genus Suberea are found in shallow waters at depths from 8 to 55 meters, in both warm temperate and tropical waters off the coasts of Victoria, New South Wales, the Great Barrier Reef, Northwest Australia, Aru \& Ki Islands, Indonesia, New Caledonia, Kermadec Islands, New Zealand, the Tropical Pacific Mexico, Clipperton Island in the Eastern Pacific, Caribbean Columbia, Gulf of Manaar, Sri Lanka, Southern India, Red Sea (Sudan and Egypt), Persian Gulf, Vema Seamount, and South Africa [23]. A common Indo-Pacific species, S. ianthelliformis (Lendenfeld, 1888), has a wide distribution over French Polynesia (Society, Marquesas, Tuamotu Archipelago Islands), Fiji, Solomon Islands, Northeast and Northwest Australia, the Philippines, South China Sea, Malaysia, and Indian Ocean Western Australia [24]. Like other marine sponge genera belonging to the order Verongida (Family: Aplysinellidae), such as Aplysinella and Porphyria, members of the genus Suberea are known to produce diverse structures of brominated tyrosine alkaloids $[25,26]$ that display a myriad of bioactivities (Table 1) including cytotoxicity [27], antimicrobial properties [28], antibacterial properties [29], kinase inhibitor production [27], and antiproliferative properties [30]. Interestingly, a recent paper by Nicacio et al. [31] reported that a culture of the marine bacterium Pseudovibrio denitrificans Ab134, isolated from the Haplosclerida sponge Arenosclera brasiliensis, was able to produce bromotyrosine-derived alkaloids. This observation highlights important questions about the discretion in considering these brominated secondary metabolites as chemical markers of the order Verongida, and for marine sponge phylogeny in general. To the best of our knowledge, previous chemical investigations were mainly focused on only six species: Suberea sp., S. aff. praetensa, S. mollis, S. creba, S. ianthelliformis, and S. clavata.

As a part of our ongoing research on biologically active marine natural products [32-37], this review comprehensively covers chemistry and biological activities of the isolated secondary 
metabolites from the marine sponges of the genus Suberea, reported over the period of 1998-2018, with a special attention to the halogenated compounds and their biosynthetic pathways.

\section{Chemistry and Biological Activities of Secondary Metabolites Isolated from the Members of the genus suberea}

\subsection{Halogenated Tyrosine Derivatives (Isoxazolines, Oxepinisoxazolines, and Phenolics)}

From Figure 1-seven cytotoxic bromotyrosine alkaloids, namely ma'edamines A and B (1 and $\mathbf{2})$ that possess a unique $2(1 \mathrm{H})$ pyrazinone motif, along with aplysamine-2 (3), purpureamines $\mathrm{H}$ and I (4 and 5), and suberedamines A and B (6 and 7) were isolated from an Okinawan Suberea sp. [38]. Biosynthetically, $\mathbf{6}$ and 7, which are precursors of $\mathbf{1}$ and 2, could be formed by the condensation of two bromotyrosine units. Compounds 1 and 2 displayed in vitro cytotoxicity against murine leukemia L1210 and KB (mouth epidermoid carcinoma) cells, with $\mathrm{IC}_{50}$ values of $4.3,3.9,5.2$ and $4.5 \mu \mathrm{g} / \mathrm{mL}$, respectively. Furthermore, these compounds also exhibited inhibitory activity against c-erbB-2 kinase, with $\mathrm{IC}_{50}$ values of 6.7 and $>10 \mu \mathrm{g} / \mathrm{mL}$, respectively. Similarly, 6 and 7 exhibited in vitro cytotoxicity against murine leukemia L1201, with $\mathrm{IC}_{50}$ values of 8.0 and $8.6 \mu \mathrm{g} / \mathrm{mL}$, and also against epidermoid carcinoma KB cells, with $\mathrm{IC}_{50}$ values of 9.0 and $>10.0 \mu \mathrm{g} / \mathrm{mL}$, respectively. Compounds 6 and 7 also showed antibacterial activity against Micrococcus luteus, with an MIC value of $12.6 \mu \mathrm{g} / \mathrm{mL}[27,38]$. Furthermore, simple bromotyrosine derivatives isolated from Suberea sp., including subereaphenol K (8) and 2-(3,5-dibromo-1-ethoxy-4-oxocyclohexa-2,5-dien-1-yl) acetamide (9), showed cytotoxicity against NIH-3T3 (mouse embryonic fibroblast), HepG2 (human liver cancer), and HT-29 (human colon adenocarcinoma) cell lines [39]. Interestingly, psammaplysins I (10), J (11), A (12), B (13), and F (14), which all possess a complex spiro-oxepinisoxazoline scaffold, were also isolated from Suberea sp. [40] (Figure 1).
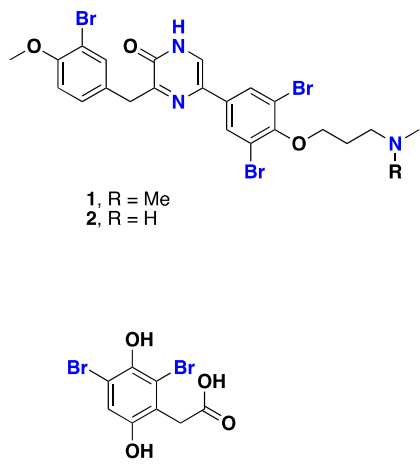

8

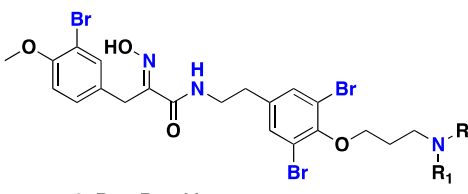

3, $\mathrm{R}_{1}=\mathrm{R}_{2}=\mathrm{Me}$ 4, $R_{1}=M e, R_{2}=H$

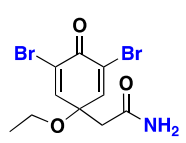

9
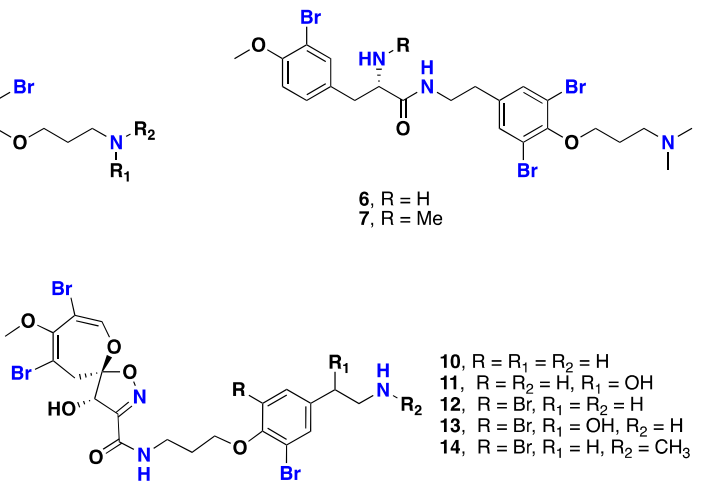

Figure 1. Chemical structures of 1-14.

From Figure 2-three complex hexabromotyrosine derivatives containing the oxazolidone moiety, namely fistularin-3 (15) and 11,17-dideoxyagelorins A (16) and B (17), along with 5-chlorocavernicolin (18), 5-bromocavernicolin (19), cavernicolin-1 (20), cavernicolin-2 (21), subereatensin (22), 2-(3',5'-dibromo-4'-hydroxyphenyl)acetamide (23), 3,5-dibromoverongiaquinol (24), and bis-oxazolidone (25) and its acetate congeners (26 and 27) were reported from the marine sponge S. aff. praetensa collected from the Gulf of Thailand [41-43]. Some of these compounds exhibited potent cytotoxicity against five human cancer cell lines: MCF-7 (breast cancer), NCI-H460 (human non-small cell lung cancer), SF268 (glioblastoma), TK-10 (human renal carcinoma), and UACC-62 (human melanoma), with $\mathrm{GI}_{50}$ values in the micromolar range [41-43]. Moreover, 15, which was also isolated from Alisina archeri, was shown to inhibit the growth of feline leukemia virus [44]. In addition to antitumor activity, 24 also displayed antibacterial activity [45]. Debitus et al. [46] found that 24, isolated from S. creba, also exhibited a chloramphenicol antibiotic-like activity (quorum sensing inhibition) against the marine bacterium Vibrio scala. Weiss et al. [47] described the isolation of $\mathbf{2 4}$ from 
the marine sponge Verongia aerophoba and its antibacterial activity against eight different Gram-positive or Gram-negative marine bacteria, including Alteromonas, Moraxella, and Vibrio sp., in addition to potent activity against the marine bacterium Photobacterium phosphoreum, with an $\mathrm{EC}_{50}$ value of $3.45 \mu \mathrm{M}$. Moreover, this compound also inhibited the growth of the marine microalgae Coscinodiscus wailesii and Prorocentrum minimum, with an $\mathrm{EC}_{50}$ of $5.6 \mu \mathrm{M}$ [47] (Figure 2).
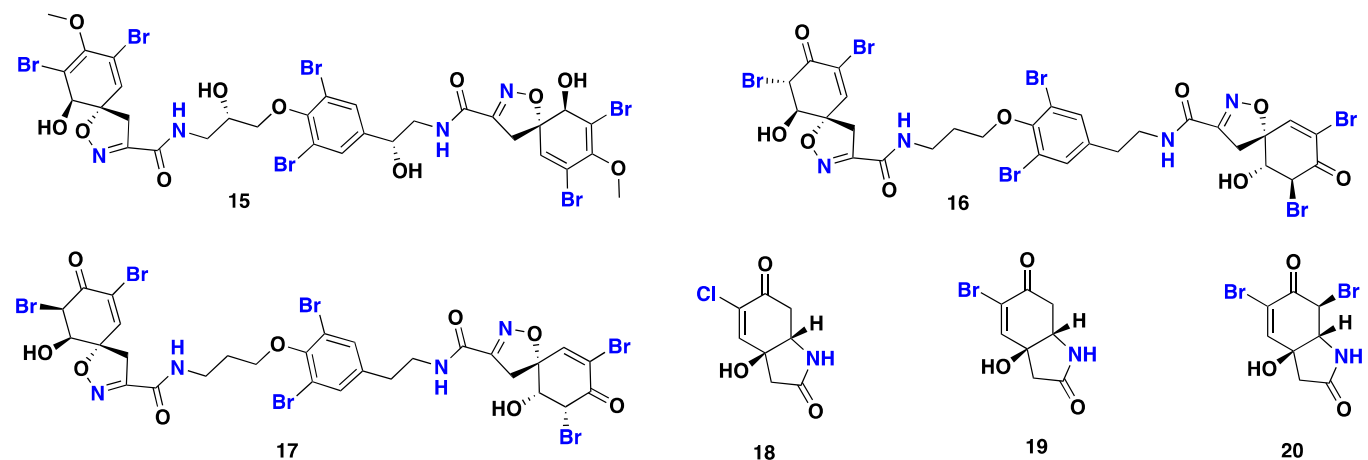

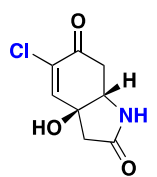

18

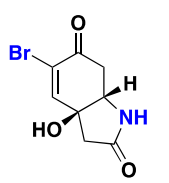

19

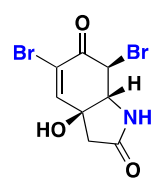

20

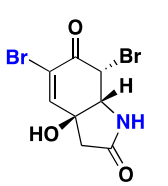

21

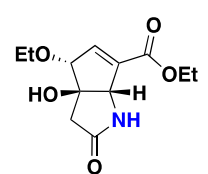

22

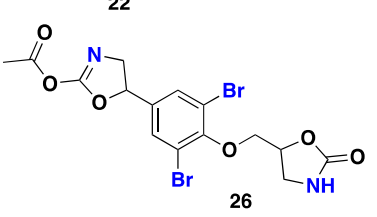

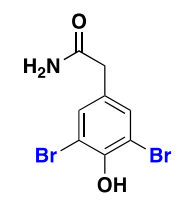

23

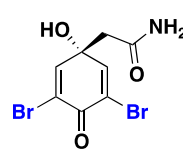

24

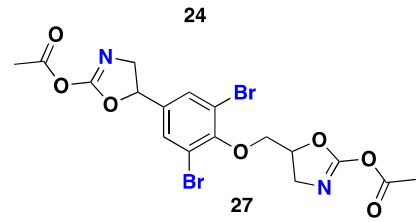

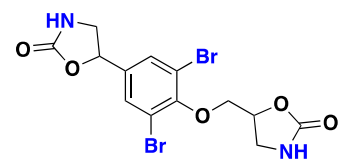

25

Figure 2. Chemical structures of 15-27.

From Figure 3-six cytotoxic and antimicrobial dibromophenol derivatives, including subereaphenol A (28), 2-(3',5'-dibromo-2'-hydroxy-4'-methoxyphenyl) acetamide (29), subereaphenol C (30), dibromoverongiaquinol (31), and bromochloroverongiaquinol (32), were isolated from S. creba [46], whereas 32 and 2-(3',5'-dibromo-4'-ethoxy-1'-hydroxy-4'methoxy-2',5'-cyclohexadien-1-yl) acetamide (33) were isolated from S. mollis, which was collected from the Egyptian Red Sea [48]. Compound 32 showed antibacterial activity against both Gram-positive (Sarcina lutea) and Gram-negative (Alcaligena faecalis and Proteus vulgaris) bacteria [49]. Compounds 23 and 30-32 [46] were re-isolated from Suberea sp., also collected from the Red Sea [50]. Compounds 23, 30 and 32 exhibited cytotoxic and antiproliferative effects against HCT-116 (human colon cancer) and HeLa (human carcinoma) cell lines, and 32 was found to be the most cytotoxic, with $\mathrm{IC}_{50}$ values of 4.5 and $10 \mu \mathrm{g} / \mathrm{mL}$, respectively. Additionally, 32 also exhibited moderate antibacterial activity against Escherichia coli, with an inhibition zone of $12 \mathrm{~mm}$ [50].

The oxazolidone-containing metabolites subereamollines A (34) and B (35), aerothionin (36), homoaerothionin (37), 11,19-dideoxyfistularin-3 (38), and (+)-aeroplysinin-1 (39) were reported from S. creba [46]. While 36 displayed a feed chemical defense role against the predatory fish Blennius sphinx [51], 39 displayed potent antibacterial activity against Staphylococcus albus, Bacillus cereus, and B. subtilis, with MIC values of $20-100 \mu \mathrm{g} / \mathrm{mL}[52,53]$, as well as cytotoxicity against a panel of tumor cell lines, including human cervix uteri, Ehrlich ascites tumor (EAT), and HeLa cell lines [54-57]. Moreover, synthetic congeners of (+)-aeroplysinin-1 showed an in vivo inhibition of the receptor tyrosine kinase (RTK) and antiproliferative activity [58]. Aeroplysinin-2 (40) and subereaphenol B (41), previously reported from the Red Sea Suberea sp. [30], were re-isolated from S. mollis also collected from the Red Sea [59] (Figure 3). 

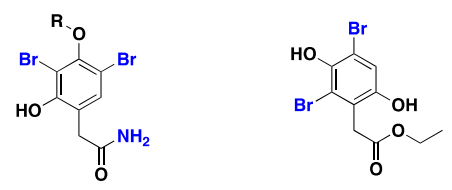

28, $R=H$
29, $R=M e$
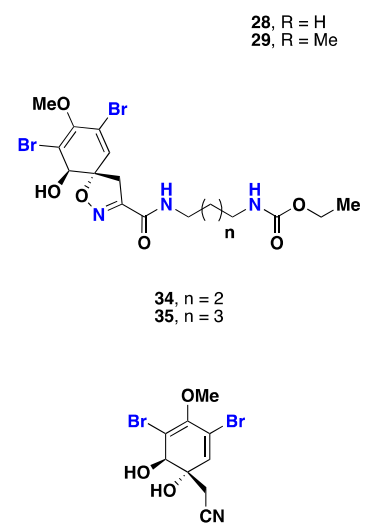

39
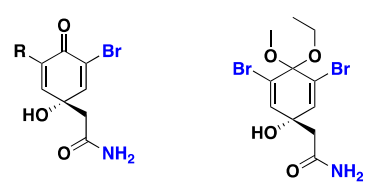

$$
\begin{aligned}
& 31, \mathrm{R}=\mathrm{Br} \\
& 32, \mathrm{R}=\mathrm{Cl}
\end{aligned}
$$

33

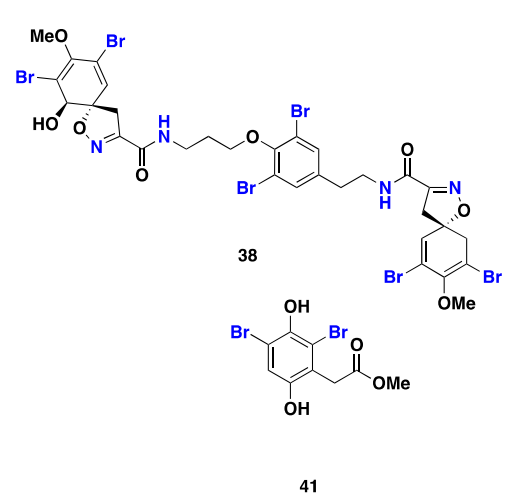

41

Figure 3. Chemical structures of 28-41.

From Figure 4-two antimicrobial brominated arginine derivatives, subereamines A and B (42 and 43), along with subereaphenol D (44), were isolated from S. mollis collected in the Egyptian Red Sea [28]. The chemical investigation of $S$. clavata extracts furnished eight guanidine-containing bromotyrosine derivatives, namely clavatadines A-E (45-49), aerophobin-1 (50), purealidin L (51), and aplysinamisine II (52) that showed inhibition against Factor XIa $[60,61]$. The antibacterial bromotyrosine alkaloids possessing polyamine motifs, ianthelliformisamines A-C (53-55), were isolated from S. ianthelliformis along with aplysamine-1 (56) and araplysillin-I (57). Compound 53 showed antibacterial activity against the Gram-negative bacterium Pseudomonas aeruginosa, with an $\mathrm{IC}_{50}$ of $6.8 \mu \mathrm{M}$ [29] (Figure 4).

From Figure 5-five antiplasmodial metabolites, including araplysillin N-20-formamide (58), araplysillin N-20-hydroxyformamide (59), araplysillin IV (60), araplysillin V (61), and araplysillin VI (62), were reported from S. ianthelliformis. Compounds 58-62 exhibited weak to moderate inhibitory activities against both chloroquine-resistant and chloroquine-sensitive Plasmodium falciparum strains $\mathrm{FcB}-1$ and 3D7, with $\mathrm{IC}_{50}$ values in the range of 1.0 to $59 \mu \mathrm{M}$, and 0.9 to $19.9 \mu \mathrm{M}$, respectively [62]. Subereamollines C and D (63 and 64), isolated from Suberea sp. collected from the Red Sea, displayed weak antiproliferative activity [30]. Psammaplysins A (65), B (66), D (67), E (68), 19-hydoxypsammaplysin E (69), psammaplysin X (70), 19-hydroxypsammaplysin $\mathrm{X}$ (71), psammaplysin Y (72), 19-hydroxyceratinamide A (73), subereamides A-C (74-76), and 12-hydroxysubereamide C (77), in addition to moloka'iamine (78), hyroxymoloka'iamine (79), ceratinamine (80) and hydroxyceratinamine (81), were isolated from a Micronesian sponge Suberea sp. These psammaplysin analogues (65-81) displayed potent cytotoxicity against six human tumor cell lines, namely HCT-15 (colon cancer), PC-3 (prostate cancer), ACHN (renal cancer), MDA-MB-231 (breast cancer), NUGC-3 (stomach cancer), and NCI-H23 (lung cancer), with GI $_{50}$ values as low as $0.8 \mu \mathrm{M}$. This suggests these compounds could serve as promising molecular templates for the development of anticancer agents [63] (Figure 5). 


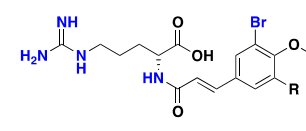

$42, \mathrm{R}=\mathrm{H}$
$43, \mathrm{R}=\mathrm{Br}$

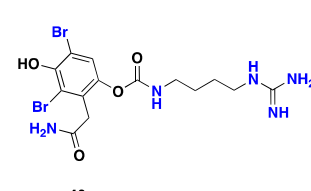

(1)

(1)

53

(1)
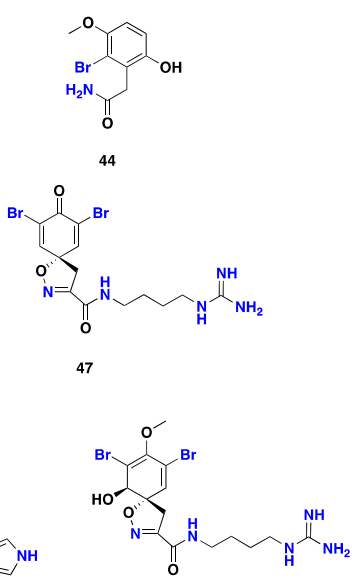

51

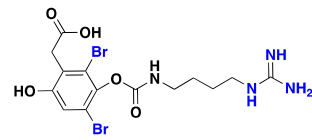

45
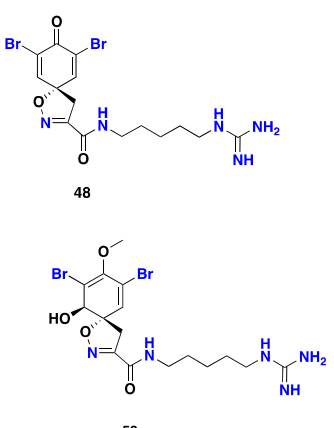

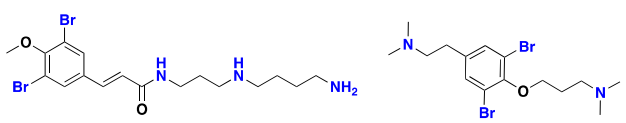

54

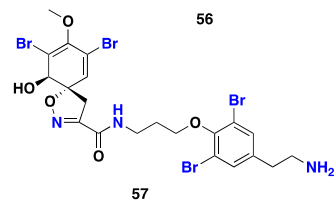

Figure 4. Chemical structures of 42-57.

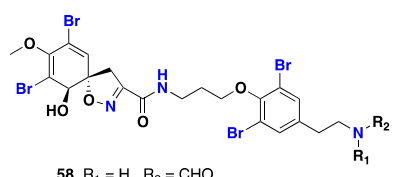

$58, \mathrm{R}_{1}=\mathrm{H} \quad \mathrm{R}_{2}=\mathrm{CHO}$
$59, \mathrm{R}_{1}=\mathrm{OH} \quad \mathrm{R}_{2}=\mathrm{CHO}$

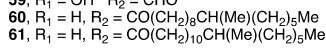

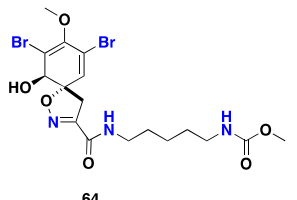

64

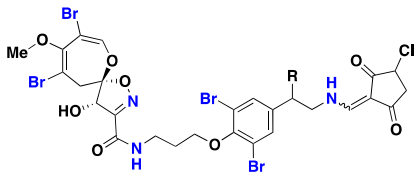

$70, \mathrm{R}=\mathrm{H}$
$71, \mathrm{R}=\mathrm{OH}$

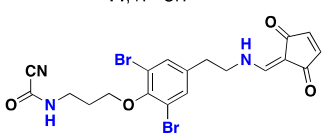

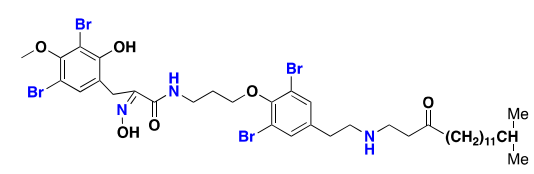

62
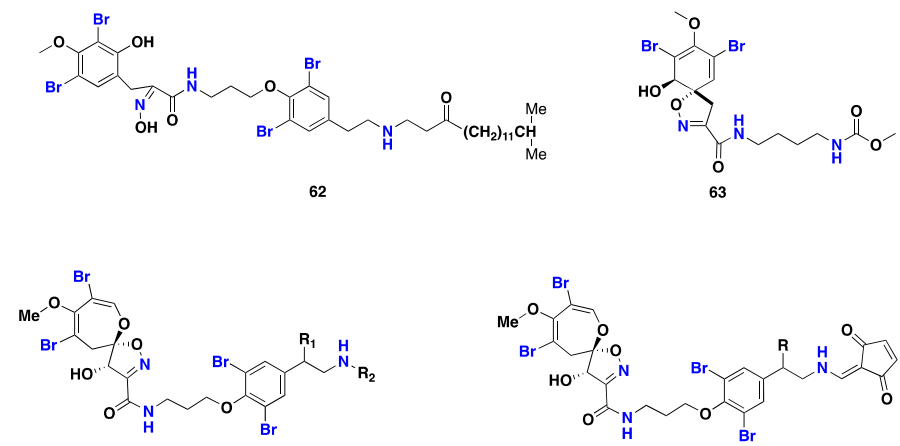

65, $R_{1}=R_{2}=H$

66, $\mathrm{R}_{1}=\mathrm{OH}, \mathrm{R}_{2}=\mathrm{H}$
$67, \mathrm{R}_{1}=\mathrm{OH}, \mathrm{R}_{2}=\mathrm{CO}\left(\mathrm{CH}_{2}\right)_{11} \mathrm{CH}\left(\mathrm{CH}_{3}\right)_{2}$

$68, \mathrm{R}=\mathrm{H}$
$69, \mathrm{R}=\mathrm{OH}$
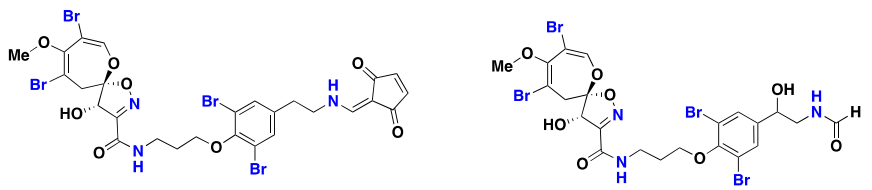

\section{2}

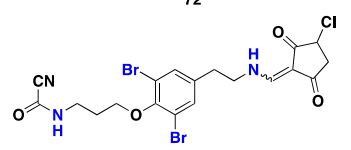

73

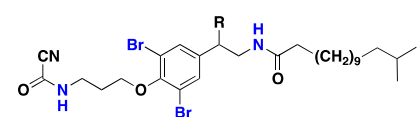

75

$\begin{aligned} 76, \mathrm{R} & =\mathrm{H} \\ 77, \mathrm{R} & =\mathrm{OH}\end{aligned}$

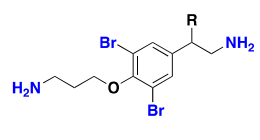

$78, \mathrm{R}=\mathrm{H}$
$79, \mathrm{R}=\mathrm{OH}$

$$
\text { (N) }
$$

$80, R=H$
$81, R=O H$

Figure 5. Chemical structures of 58-81. 
From Figure 6-Al-Mourabit et al. [64] reported the isolation of eight tetrabromotyrosine alkaloids, psammaplysenes F-I (82-85), and anomoians C-F (86-89), along with the known natural products psammaplysene $\mathrm{D}(\mathbf{9 0})$ and $N, N$-dimethyldibromotyramine (91), from the Polynesian sponge S. ianthelliformis. Compounds 82,83 and $86-89$ exhibited moderate cytotoxicity against the KB cell line, whereas 90 was the most potent with an $\mathrm{IC}_{50}$ of $0.7 \mu \mathrm{M}$. Although the structures of 88 and 89 resemble that of 90 , they exhibited weaker cytotoxicity than $\mathbf{9 0}$. It can be hypothesized that the presence of the double bond in the 3,5-dibromo $p$-hydroxycinnamoyl moiety in 90, instead of the amino or alkylamino group on the carbon adjacent to the amide carbonyl in $\mathbf{8 8}$ and $\mathbf{8 9}$, was essential for this activity. Curiously, 82, which contains a double bond in the 3,5-dibromo $p$-hydroxycinnamoyl moiety as in 90 , but lacks the $N, N$-dimethylaminopropyl substituent on the phenolic hydroxyl group of the 3,5-dibromo $p$-hydroxycinnamoyl moiety, displayed much weaker cytotoxicity than $\mathbf{9 0}$. Therefore, both $N, N$-dimethylaminopropyl and trans-3,5-dibromo $p$-hydroxycinnamoyl moieties seem to be essential for the cytotoxicity for this series of compounds. Moreover, $\mathbf{9 0}$ showed a promising in vitro acetylcholinesterase inhibitory activity with an $\mathrm{IC}_{50}$ of $1.3 \mu \mathrm{M}$, as well as a potent activity against fish antifeedant activity [34,64] (Figure 6).

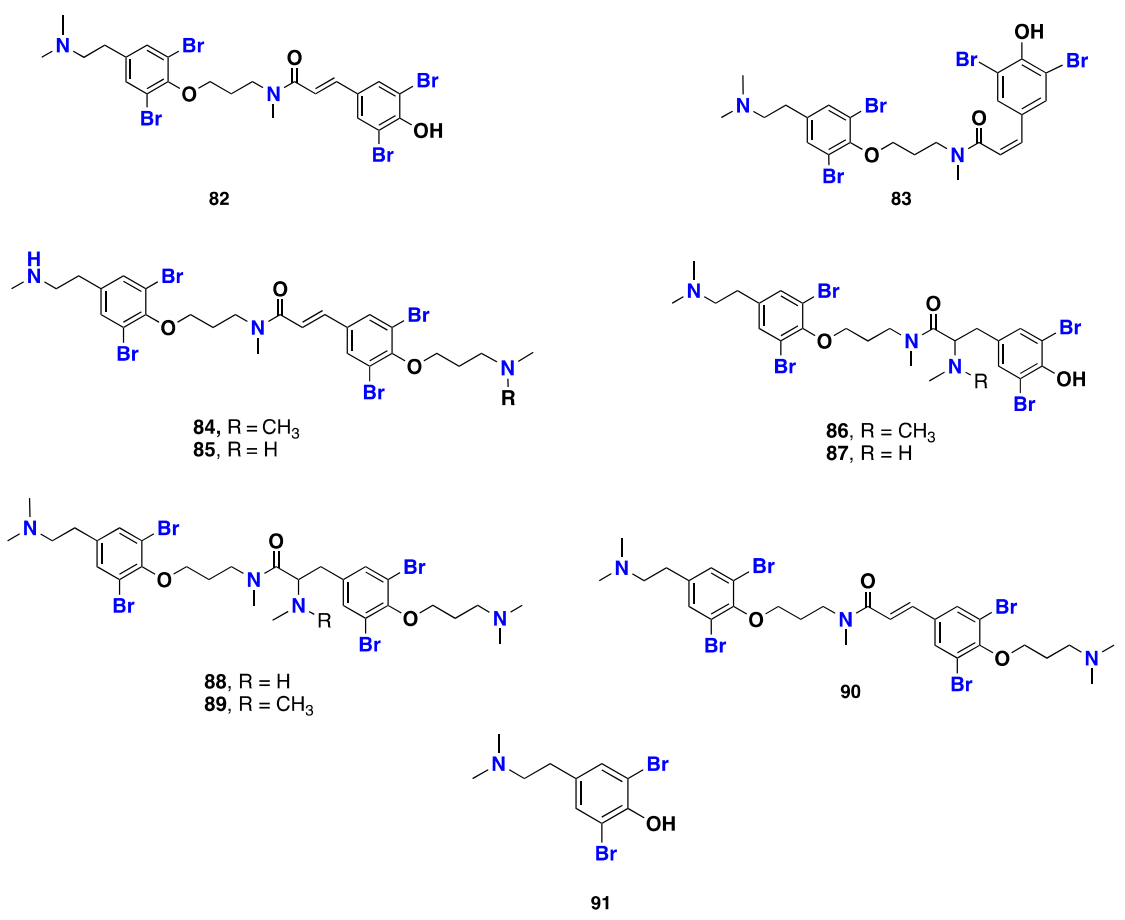

Figure 6. Chemical structures of 82-91.

2.2. Non-halogenated Derivatives (Tyrosine, Aaptamine, Pyrrole, Quinolines, Isopernoids, Sesterterpenoids and Macrolides)

From Figure 7-lihouidine (92), a polycyclic alkaloid featuring two modified aaptamine moieties, was obtained from Suberea n. sp. collected in Australia. Compound 92 displayed moderate cytotoxicity against P388D1 (mouse lymphoma cells) with an $\mathrm{IC}_{50}$ of $3 \mu \mathrm{g} / \mathrm{mL}$ [65]. Interestingly, structurally less complex metabolites such as 1-(hydroxy(1H-pyrrol-2-yl)methyl)guanidine (93) and 4-(2-amino-3-methylbut-3-en-1-yl) phenol (94) were also isolated from the Red Sea Suberea sp. Compound 93 exhibited low cytotoxicity against HCT-116 and HeLa cell lines, with $\mathrm{IC}_{50}$ values of 25 and $30 \mu \mathrm{g} / \mathrm{mL}$, respectively, whereas 94 showed moderate cytotoxicity with $\mathrm{IC}_{50}$ values of 20 and $27 \mu \mathrm{g} / \mathrm{mL}$, respectively. Furthermore, 93 and $\mathbf{9 4}$ displayed moderate antifungal activity against Candida albicans at a concentration of $100 \mu \mathrm{g}$, with inhibition zones of 8 and $15 \mathrm{~mm}$, respectively [50]. 5-Hydroxyxanthenuric acid (95) and xanthurenic acid (96) were co-isolated, along with 82-91, from the Polynesian S. ianthelliformis [64]. 

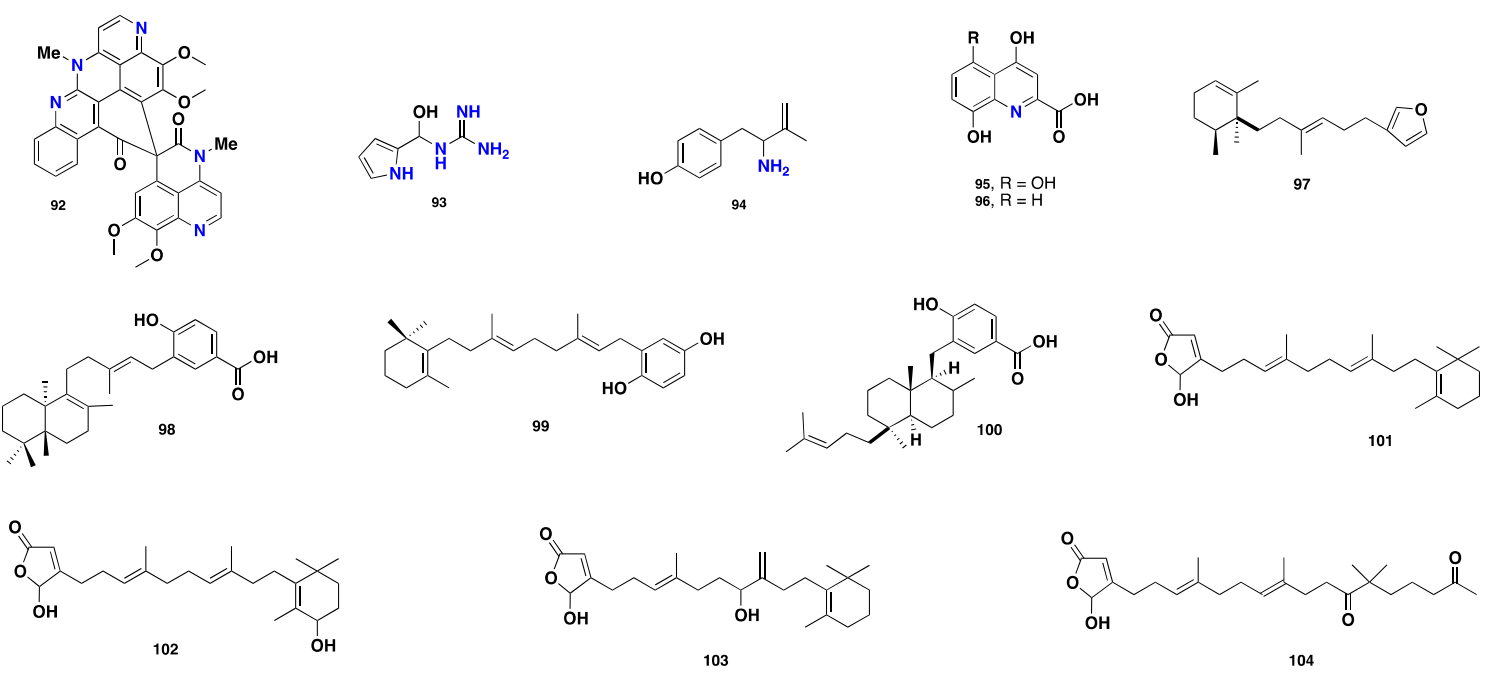

Figure 7. Chemical structures of 92-104.

A few non-brominated metabolites, including terpenoid compounds such as $(+)-(5 S, 6 S)$-subersin (97) and three meroditerpenoids including (-)-subersic acid (98), jaspaquinol (99), and (-)-jaspic acid (100), were also reported from Suberea sp. These compounds showed inhibitory activity against human 15-lipoxygenase, with $\mathrm{IC}_{50}$ values $>100,15,0.3$, and $1.4 \mu \mathrm{M}$, respectively [66]. Four sesterterpenoids, namely luffariellolide (101), 18-hydroxyluffariellolide (102), acantholides A (103), and C (104), were reported from Suberea sp. collected from the Philippines [67]. These naturally occurring compounds, along with synthetically prepared analogues, were evaluated for their antimicrobial activity against two Gram-negative bacterial strains, Klebsiella pneumoniae and Salmonella enterica. Compound 101 displayed moderate activity against $S$. enterica with an MIC value of $4 \mu \mathrm{g} / \mathrm{mL}$, but no activity against K. pneumoniae (MIC value $>64 \mu \mathrm{g} / \mathrm{mL}$ ), while 102 exhibited moderate activity against K. pneumoniae (MIC value of $8 \mu \mathrm{g} / \mathrm{mL}$ ) and weak activity against S. enterica (MIC value $16 \mu \mathrm{g} / \mathrm{mL}$ ) [67] (Figure 7).

From Figure 8-additionally, three potent cytotoxic glycosylated oxazole-bearing macrolides, 105-107, were isolated from S. creba collected in New Caledonia. These compounds exhibited strong cytotoxicity against seven tumor cell lines, including A549 (human lung carcinoma), BxPC3 (Human primary pancreatic adenocarcinoma), KB, KB-V1 (human cervix carcinoma), LoVo (human colon carcinoma), Namalwa (human Burkitt lymphoma), and SKOV3 ovarian carcinoma), with $\mathrm{EC}_{50}$ values ranging from micromolar to picomolar [68,69] (Figure 8).

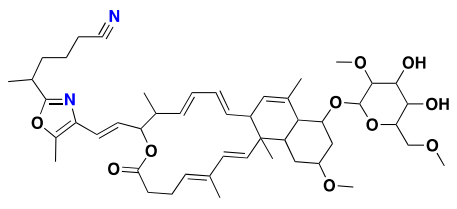

105

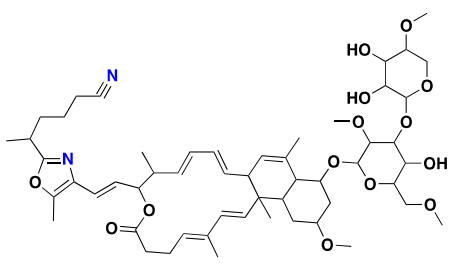

106

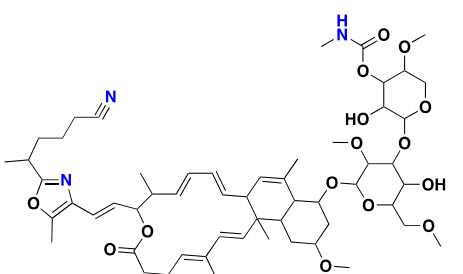

107

Figure 8. Chemical structures of 105-107.

From Figure 9-curiously, only few metabolites have been reported from Suberea sponge-associated microorganisms. These include a dibenzopyrazine alkaloid (108) and five quinolone derivatives (109-113), along with the 2,5-diketopeiprazine alkaloid (114) produced by a marine bacterium Pseudomonas sp. isolated from S. creba. Compound 109 displayed promising in vitro antibacterial activity against the marine bacterium V. scala [46] (Figure 9). 
<smiles>NC(=O)c1cccc2nc3ccccc3nc12</smiles>

108<smiles>[R]c1cc(=O)c2ccccc2[nH]1</smiles>

109, $\mathrm{R}=n-\mathrm{C}_{7} \mathrm{H}_{15}$

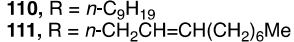<smiles>[R]C1(O)C(=O)Nc2ccccc2C1=O</smiles>

$112, \mathrm{R}=n-\mathrm{C}_{7} \mathrm{H}_{15}$<smiles>OC1=CC(O)(P)N(O)c2ccccc21</smiles>

113, $\mathrm{R}=n-\mathrm{C}_{7} \mathrm{H}_{15}$

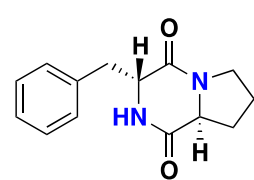

114

Figure 9. Chemical structures of 108-114.

Table 1. Summary of secondary metabolites isolated from marine sponges of the genus Suberea, and their biological activities.

\begin{tabular}{|c|c|c|c|c|}
\hline Compound & Species & Local of Collection & Biological Activity & References \\
\hline $1-5$ & Suberea sp. & Okinawa & Cytotoxic, kinase inhibitors & [27] \\
\hline $6-7$ & Suberea sp. & Okinawa & Cytotoxic, antibacterial & [38] \\
\hline $8-9$ & Suberea sp. & Okinawa & Cytotoxic & [39] \\
\hline $10-14$ & Suberea sp. & Guam & $\mathrm{Nr}$ & [40] \\
\hline $15-27$ & S. aff. praetensa & Thailand & Cytotoxic & [41-43] \\
\hline 24 & S. creba & Coral Sea, Australia & Antiviral, antibacterial & [45-47] \\
\hline $28-32$ & S. creba & Coral Sea, Australia & Cytotoxic, antimicrobial & [46] \\
\hline $32-33$ & S. mollis & Red Sea, Egypt & Cytotoxic, antimicrobial & {$[48,49]$} \\
\hline $23,30-32$ & Suberea sp. & Red Sea, Egypt & Cytotoxic, antiproliferative, antibacterial & [50] \\
\hline $34-39$ & S. creba & Coral Sea, Australia & $\begin{array}{l}\text { Antimicrobial, Cytotoxic, tyrosine kinase } \\
\text { inhibitor, antiproliferative }\end{array}$ & $\begin{array}{c}{[46,51-53]} \\
{[54-58]}\end{array}$ \\
\hline $40-41$ & $\begin{array}{l}\text { Suberea sp. } \\
\text { S. mollis }\end{array}$ & $\begin{array}{l}\text { Red sea, Egypt } \\
\text { Red Sea, Egypt }\end{array}$ & $\begin{array}{l}\text { Cytotoxic, antioxidant } \\
\qquad \mathrm{Nr}\end{array}$ & $\begin{array}{l}{[30]} \\
{[59]}\end{array}$ \\
\hline $42-44$ & S. mollis & Red Sea, Egypt & Antimicrobial & [28] \\
\hline $45-52$ & S. clavata & Great Barrier Reef, Australia & Plasma thromboplastin inhibitor & {$[60,61]$} \\
\hline $53-57$ & S. ianthelliformis & $\begin{array}{l}\text { Manta Ray Bommie, } \\
\text { Australia }\end{array}$ & Antibacterial & [29] \\
\hline $58-62$ & S. ianthelliformis & Solomon Islands & Antiplasmodial & [62] \\
\hline $63-64$ & Suberea sp. & Red Sea, Egypt & Antiproliferative & [30] \\
\hline $65-81$ & Suberea sp. & Micronesia & Cytotoxic & [63] \\
\hline $82-91$ & S. ianthelliformis & French Polynesia & Cytotoxic, acetylcholinesterase inhibitor & {$[34,64]$} \\
\hline 92 & Suberea sp. & Lihou Reef, Australia & Cytotoxic & [65] \\
\hline 93-94 & Suberea sp. & Red Sea, Egypt & Cytotoxic, antimicrobial & [50] \\
\hline $95-96$ & S. ianthelliformis & French Polynesia & $\mathrm{Nr}$ & [64] \\
\hline 97-100 & Suberea sp. & Papua New Guinea & Human 15-Lipoxygenase inhibitor & [66] \\
\hline $101-104$ & Suberea sp. & Philippines & Antimicrobial & [67] \\
\hline 105-107 & S. creba & New Caledonia & Cytotoxic & {$[68,69]$} \\
\hline $108-114$ & S. creba & New Caledonia & Antibacterial & [46] \\
\hline
\end{tabular}

Nr: Not reported.

\section{Proposed Biogenetic Pathways for Different Bromotyrosine Derivatives}

From Figure 10-earlier biosynthetic studies on bromotyrosine derivatives showed that the metabolic cascade is initiated by bromination of tyrosine (I) with bromoperoxidase enzymes to give a brominated tyrosine intermediate II. Then, II can be transformed into $\mathbf{V}$ (like purpurealidins A-F) or can undergo further reactions. Route A: Oxidation of the amine to an oxime, affording the intermediate VI. Route B: O-methylation of II, followed by the oxidation of the amine functionality to an oxime (III) or producing compounds such as purpuramines and aplysamines (VIII). Moreover, the first pathway (route A) could also afford phenolic nitriles (IX) and amides (XII), or alternatively, can undergo an epoxidation $\left(\mathbf{A}_{\mathbf{1}}\right)$ to form an intermediate VII. This in turn leads to either (a) the isoxazoline ring system (XIV), producing metabolites such as aerothionin, homoaerothionin, purealdin $\mathrm{Q}$, and purpurealidins A and J, or (b) the oxepine ring system (XIII), as found in the psammaplysins. Moreover, the isoxazoline ring (XIV) can undergo further oxidation and dehydration leading to XV (like purpurealidin B). On the other hand, route $\mathbf{B}$ could lead to the pathway featuring a dehydration/decarboxylation $\left(\mathbf{B}_{\mathbf{1}}\right)$ to afford the O-methylated nitriles (IV) [26,70-72] (Figure 10). 

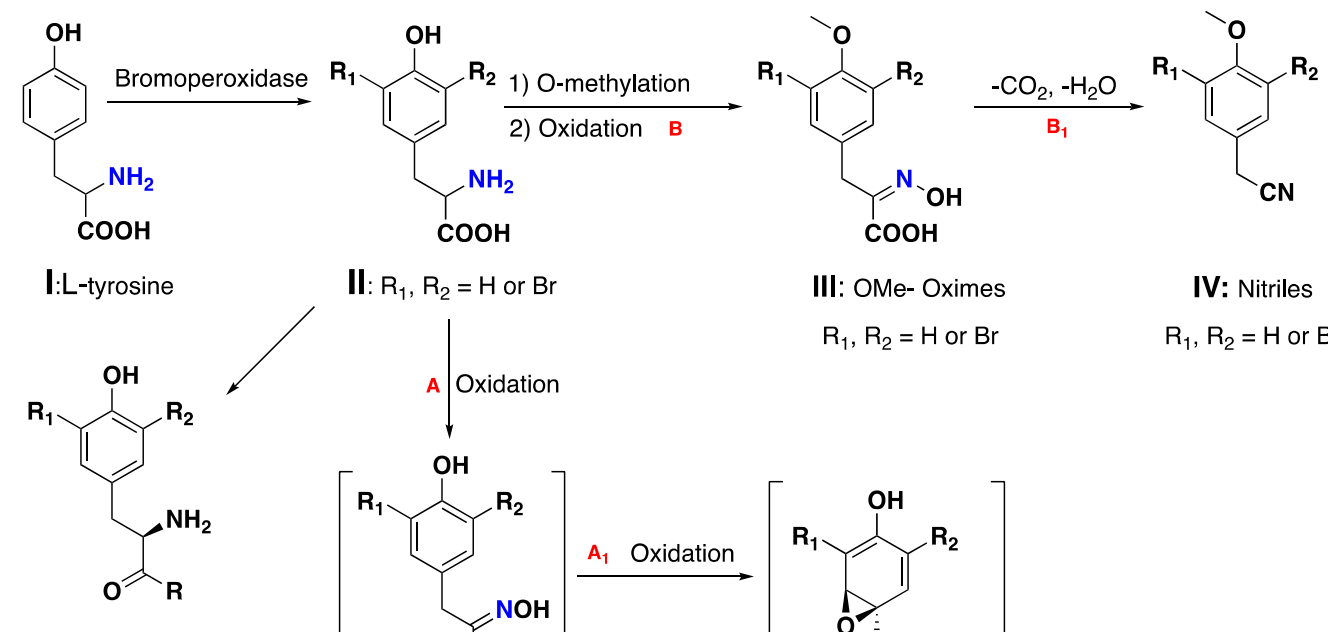

V: $\mathrm{R}_{1}, \mathrm{R}_{2}=\mathrm{H}$ or $\mathrm{Br}$

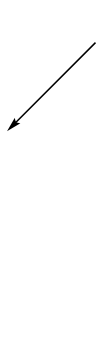

II: $\mathrm{R}_{1}, \mathrm{R}_{2}=\mathrm{H}$ or $\mathrm{Br}$

III: OMe- Oximes

IV: Nitriles

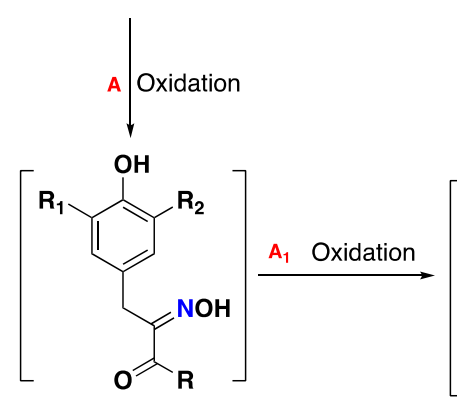

$\mathrm{R}_{1}, \mathrm{R}_{2}=\mathrm{H}$ or $\mathrm{Br}$

$\mathrm{R}_{1}, \mathrm{R}_{2}=\mathrm{H}$ or $\mathrm{Br}$
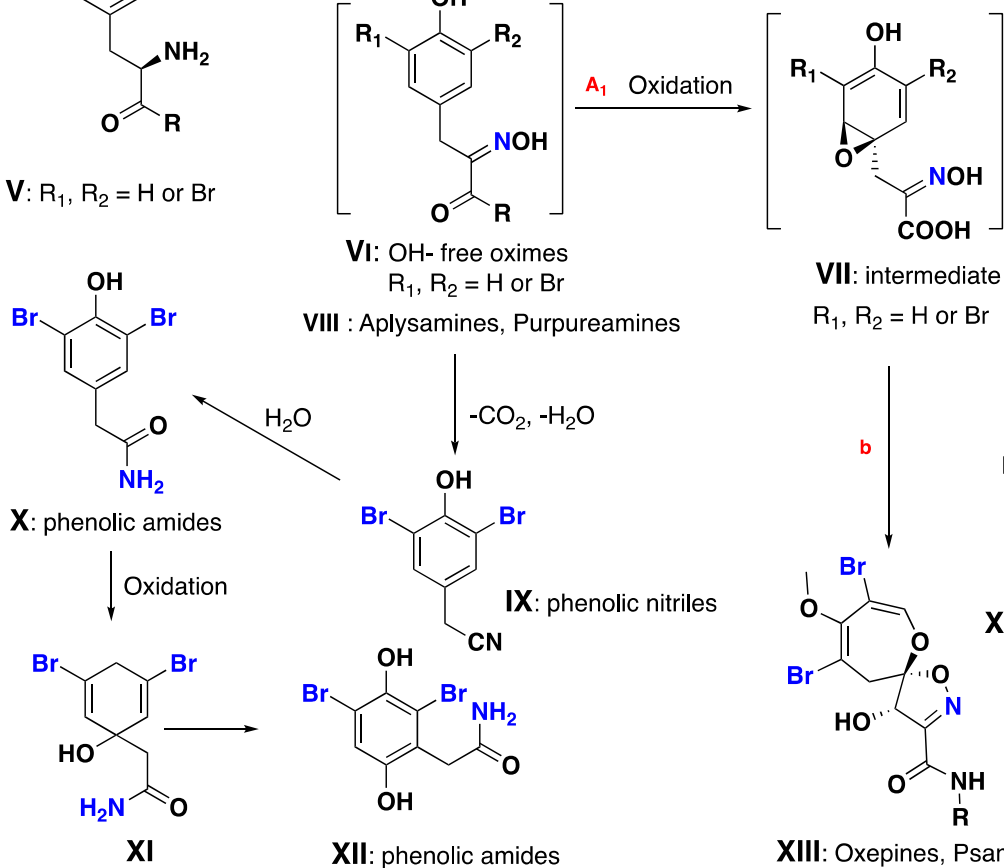

VII: intermediate

$\mathrm{R}_{1}, \mathrm{R}_{2}=\mathrm{H}$ or $\mathrm{Br}$

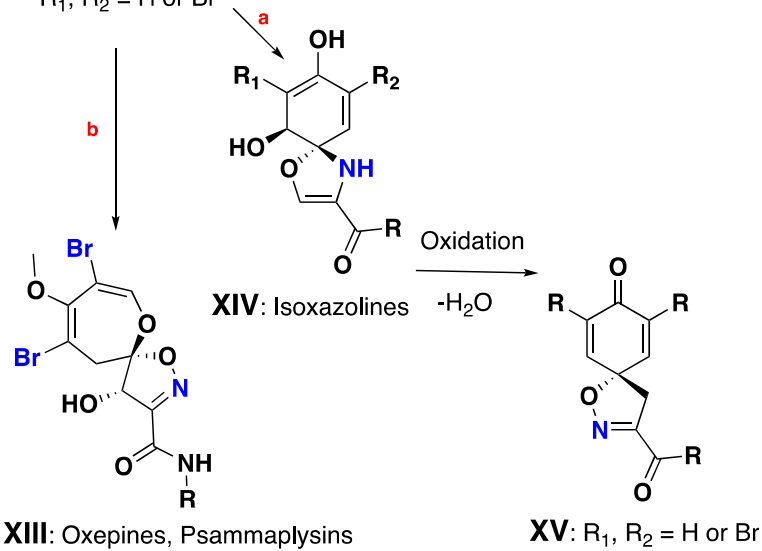

Figure 10. Proposed biogenetic pathway of different bromotyrosine derivatives.

\section{Conclusions}

The present review highlights a comprehensive literature survey covering the chemical and biological remarks of secondary metabolites isolated from marine sponges belonging to the genus Suberea over the period of 1998-2018. One hundred and fourteen isolated metabolites are categorized into two main groups, presenting an array of molecular architectures that display a vast spectrum of bioactivities. Additionally, a brief insight of the proposed biogenetic pathways leading to different bromotyrosine motifs is also discussed. The chemodiversity and bioactivities of the metabolites from the sponges of this genus make them interesting targets for further exploration to obtain novel compounds with therapeutic potentiality. Furthermore, this systematic review provides evidence that a myriad of secondary metabolites reported from members of the genus Suberea are structurally unique and exhibit a variety of biological/pharmacological activities, although cytotoxic activity predominated. Moreover, it can be observed that the habitats of these sponges also influence the types of compounds and consequent biological activities. These findings can be helpful in the bioprospecting process of marine sponges of this genus, and in finding new compounds as potential targets for further drug development in different therapeutic areas.

Author Contributions: A.E.-D. designed and elaborated the manuscript. A.G.A., O.K.H., M.A.T., M.A.-M., J.N.A.H., and N.S. added valuable comments. A.A.-M. and A.K. critically revised and improved the manuscript. All the authors read and approved the final version of the manuscript. 
Funding: This work was supported by the mission sector of the Ministry of High Education of the Arab Republic of Egypt (Egyptian Cultural Bureau in Paris, France) and CIIMAR (Portugal); A. El-Demerdash's Ph.D. was granted and completely funded. A.G. Atanasov acknowledges the support by the Polish KNOW (Leading National Research Centre) Scientific Consortium "Healthy Animal-Safe Food," decision of Ministry of Science and Higher Education No. 05-1/KNOW2/2015. A. Kijjoa thanks the support from the Strategic Funding UID/Multi/04423/2013 through national funds provided by the Foundation for Science and Technology (FCT) and European Regional Development Fund (ERDF), in the framework of the program PT2020.

Conflicts of Interest: The authors declare no conflict of interest.

\section{Abbreviations}

The following abbreviations are used in this manuscript:

$\mathrm{GI}_{50} \quad$ Half maximal growth inhibition

Factor XIa Plasma thromboplastin antecedent

$\mathrm{IC}_{50} \quad$ Half maximal inhibitory concentration

MIC Minimum Inhibitory concentration

\section{References}

1. Bourguet-Kondracki, M.L.; Kornprobst, J.M. Promising Marine Molecules in Pharmacology. Outstanding Marine Molecules, 1st ed.; La Barre, S., Kornprobst, J.M., Eds.; Wiley-Blackwell: Weinheim, Germany, 2014; pp. 243-264.

2. Jiménez, C. Marin natural products in medicinal chemistry. ACS Med. Chem. Lett. 2018, 9, 959-961. [CrossRef] [PubMed]

3. Mehbub, M.F.; Lei, J.; Franco, C.; Zhang, W. Marine Sponge Derived Natural Products between 2001 and 2010: Trends and Opportunities for Discovery of Bioactives. Mar. Drugs 2014, 12, 4539-4577. [CrossRef] [PubMed]

4. Martins, A.; Vieira, H.; Gaspar, H.; Santos, S. Marketed marine natural products in the pharmaceutical and cosmeceutical Industries: Tips for success. Mar. Drugs 2014, 12, 1066-1101. [CrossRef] [PubMed]

5. Blunt, J.W.; Copp, B.R.; Keyzers, R.A.; Munro, M.H.; Prinsep, M.R. Marine natural products. Nat. Prod. Rep. 2016, 33, 382-431. [CrossRef] [PubMed]

6. Blunt, J.W.; Copp, B.R.; Keyzers, R.A.; Munro, M.H.; Prinsep, M.R. Marine natural products. Nat. Prod. Rep. 2017, 34, 235-294. [CrossRef] [PubMed]

7. Blunt, J.W.; Carroll, A.R.; Copp, A.R.; Davis, R.A.; Keyzers, R.A.; Prinsep, M.R. Marine natural Products. Nat. Prod. Rep. 2018, 35, 8-53. [CrossRef]

8. Montaser, R.; Luesch, H. Marine natural products: A new wave of drugs. Future Med. Chem. 2011, 3, 1475-1489. [CrossRef] [PubMed]

9. Rangel, M.; Falkenberg, M. An overview of the marine natural products in clinical trials and on the market. J. Coast. Life Med. 2015, 3, 421-428. [CrossRef]

10. Patridge, E.; Gareiss, P.; Kinch, M.S.; Hoyer, D. An analysis of FDA-approved drugs: Natural products and their derivatives. Drug Discov. Today 2016, 21, 204-207. [CrossRef]

11. Bergquist, P.R. Dictyoceratida, Dendroceratida and Verongida from the New Caledonia Lagoon (Porifera: Demospongiae). Mem. Queensl. Mus. 1995, 38, 1-51.

12. Hooper, J.N.A.; Van Soest, R.W.M. Systema Porifera. A Guide to the Classification of Sponges; Kluwer Academic/Plenum Publishers: New York, NY, USA, 2002.

13. Gómez, P.; Bakus, G. Aplysina gerardogreeni and Aplysina aztecus (Porifera: Demospongiae) New Species from the Mexican Pacific; Anales del Instituto de Ciencias del Mar y Limnología, Universidad Nacional Autónoma de México: Mexico City, Mexico, 1992; pp. 175-180.

14. Pulitzer-Finali, G. Some new or little-known sponges from the Great Barrier Reef of Australia. Bol. Mus. Istituti Biol. Univ. Genova 1982, 48, 87-141.

15. Lendenfeld, R. Descriptive Catalogue of the Sponges in the Australian Museum, Sidney; Taylor \& Francis: London, UK, 1888.

16. Van Soest, R.W.M.; Kaiser, K.; van Syoc, R. Sponges from Clipperton Island, East Pacific. Zootaxa 2011, 2839, 1-46. [CrossRef] 
17. Hofman, C.C.; Kielman, M. The excavating sponges of the Santa-Marta area, Colombia, with description of a new species. Bijdr. Dierkd. 1992, 61, 205-217.

18. Carter, H.J. Report on specimens dredged up from the Gulf of Manaar and presented to the Liverpool Free Museum by Capt. W. H. Cawne Warren. Ann. Mag. Nat. Hist. 1880, 6, 35-61. [CrossRef]

19. Kelly, M.; Amirapu, S.; Mills, S.; Page, M.; Reiswig, H.M. Kermadec Islands sponge biodiversity: A review and description of a new species, Suberea meandrina sp. nov. (Demospongiae, Verongiida, Aplysinellidae). Bull. Auckland Mus. 2015, 20, 312-315.

20. Row, R.W.H. Reports on the marine biology of the Sudanese Red Sea, from collections made by Cyril Crossland, M.A., B.Sc., F.Z.S. XIX. Report on the sponges collected by Mr. Cyril Crossland in 1904-5. Part II. Non-calcarea. J. Linn. Soc. Zool. 1911, 31, 287-400. [CrossRef]

21. Lévi, C. Spongiaires du Vema Seamount (Atlantique Sud). Bull. Mus. Natl. Hist. Nat. 1969, 41, 952-973.

22. Gugel, J.; Wagler, M.; Brümmer, F. Porifera, one new species Suberea purpureaflava n. sp. (Demospongiae, Verongida, Aplysinellidae) from northern Red Sea coral reefs, with short descriptions of Red Sea Verongida and known Suberea species. Zootaxa 2011, 2994, 60-68.

23. Van Soest, R.W.M.; Boury-Esnault, N.; Hooper, J.N.A.; Rützler, K.; de Voogd, N.J.; Alvarez, B.; Hajdu, E.; Pisera, A.B.; Manconi, R.; Schönberg, C.; et al. World Porifera Database. 2018. Available online: http: / / www.marinespecies.org/porifera (accessed on 9 January 2019).

24. Hall, K.A.; Hooper, J.N.A. QM0012 Suberea ianthelliformis (Lendenfeld, 1888). SpongeMaps: An Online Community for Taxonomy and Identification of Sponges. 2014. Available online: http:/ /www.spongemaps. org (accessed on 9 January 2019).

25. Abou El-Ezz, R.; Ibrahim, A.; Habib, E.; Wahba, A.; Kamel, H.; Afifi, M.; Hassanean, H.; Ahmed, S. Review of natural products from marine organisms in the Red Sea. Int. J. Pharm. Sci. Res. 2017, 8, 940-974.

26. Peng, J.; Li, J.; Hamann, M.T. The Marine Bromotyrosine Derivatives. In The Alkaloids: Chemistry and Biology; Cordell, G.A., Ed.; Academic Press: Cambridge, MA, USA, 2005; Volume 61, pp. 59-262.

27. Hirano, K.; Kubota, T.; Tsuda, M.; Watanabe, K.; Fromont, J.; Kobayashi, J. Ma'edamines A and B, cytotoxic bromotyrosine alkaloids with a unique $2(1 \mathrm{H})$ pyrazinone ring from Sponge Suberea sp. Tetrahedron 2002, 56, 8107-8110. [CrossRef]

28. Shaala, L.A.; Bamane, F.H.; Badr, J.M.; Youssef, D.T.A. Brominated arginine-derived alkaloids from the Red Sea sponge Suberea mollis. J. Nat. Prod. 2001, 74, 1517-1520. [CrossRef] [PubMed]

29. Xu, M.; Davis, R.A.; Feng, Y.; Sykes, M.L.; Shelper, T.; Avery, V.M.; Camp, D.; Quinn, R.J. Ianthelliformisamines A-C, antibacterial bromotyrosine-derived metabolites from the marine sponge Suberea ianthelliformis. J. Nat. Prod. 2012, 75, 1001-1005. [CrossRef] [PubMed]

30. Shaala, L.A.; Youssef, D.T.A.; Badr, J.M.; Sulaiman, M.; Kherd, A. Bioactive brominated metabolites from the Red Sea sponge Suberea mollis. Mar. Drugs 2015, 13, 1621-1631. [CrossRef] [PubMed]

31. Nicacio, K.J.; Ióca, L.P.; Fróes, A.M.; Leomil, L.; Appolinario, L.R.; Thompson, C.C.; Thompson, F.L.; Ferreira, A.G.; Williams, D.E.; Andersen, R.J.; et al. Cultures of the marine bacterium Pseudovibrio denitrificans Ab134 produce bromotyrosine-derived alkaloids previously only isolated from marine sponges. J. Nat. Prod. 2017, 80, 235-240. [CrossRef] [PubMed]

32. El-Demerdash, A.; Moriou, C.; Martin, M.T.; Rodrigues-Stien, A.; Petek, S.; Demoy-Schnider, M.; Hall, K.; Hooper, J.N.A.; Debitus, C.; Al-Mourabit, A. Cytotoxic guanidine alkaloids from a French Polynesian Monanchora n. sp. sponge. J. Nat. Prod. 2016, 79, 1929-1937. [CrossRef] [PubMed]

33. El-Demerdash, A.; Moriou, C.; Martin, M.T.; Petek, S.; Debitus, C.; Al-Mourabit, A. Unguiculins A-C: Cytotoxic bis-guanidine alkaloids from the French Polynesian sponge, Monanchora n. sp. Nat. Prod. Res. 2017, 32, 1512-1517. [CrossRef] [PubMed]

34. El-Demerdash, A. Isolation of Bioactive Marine Natural Products and Bio-Inspired Synthesis of Fused Guanidinic Tricyclic Analogues. Ph.D. Thesis, University of Paris-Saclay, Paris, France, 2016.

35. El-Demerdash, A.; Atanasov, A.G.; Bishayee, A.; Abdel-Mogib, M.; Hooper, J.N.A.; Al-Mourabit, A. Batzella, Crambe and Monanchora: Highly prolific marine sponge genera yielding compounds with potential applications for cancer and other therapeutic areas. Nutrients 2018, 10, 33. [CrossRef] [PubMed]

36. El-Demerdash, A.; Tammam, M.A.; Atanasov, A.G.; Hooper, J.N.A.; Al-Mourabit, A.; Kijjoa, A. Chemistry and biological activities of the marine sponges of the genera Mycale (Arenochalina), Biemna and Clathria. Mar. Drugs 2018, 16, 214. [CrossRef] [PubMed] 
37. El-Demerdash, A.; Petek, S.; Debitus, C.; Al-Mourabit, A. Fatty Acids Pattern from the French Polynesian Monanchora n. sp. Marine Sponge. Chem. Nat. Compd. 2018, 54, 1134. [CrossRef]

38. Tsuda, M.; Sakuma, Y.; Kobayashi, J. Suberedamines A and B, new bromotyrosine alkaloids from a sponge Suberea species. J. Nat. Prod. 2001, 64, 950-982. [CrossRef]

39. Shaker, K.H.; Zinecker, H.; Ghani, M.A.; Imhoff, J.F.; Schneider, B. Bioactive metabolites from the sponge Suberea sp. Chem. Biodivers. 2010, 7, 2880-2887. [CrossRef] [PubMed]

40. Wright, A.D.; Scupp, P.J.; Scror, J.P.; Engemann, A.; Rohde, S.; Kelmna, D.; Voogd, N.; Carroll, A.; Motti, C.A. Twilight zone sponges from Guam yield theonellin isocyanate and psammaplysins I and J. J. Nat. Prod. 2012, 75, 502-506. [CrossRef] [PubMed]

41. Kijjoa, A.; Watanadilok, R.; Sonchaeng, P.; Silva, A.M.S.; Eaton, G.; Herz, W. 11,17-Dideoxyagelorin A and B, new bromotyrosine derivatives and analogs from the marine sponge Suberea aff. praetensa. Z. Naturforsch. 2001, 56, 1116-1119. [CrossRef]

42. Kijjoa, A.; Watanadilok, R.; Sonchaeng, P.; Sawangwong, P.; Pedro, M.; Nascimento, M.S.J.; Silva, A.M.S.; Eaton, G.; Herz, W. Further halotyrosine derivatives from the marine sponge Suberea aff. praetensa. Z. Naturforsch. 2002, 57, 732-738. [CrossRef]

43. Kijjoa, A.; Watanadilok, R.; Sonchaeng, P.; Puchakarn, S.; Sawangwong, P.; Herz, W. Bromotyrosine derivatives from the marine sponge Suberea aff. praetensa. Bol. Mus. Ist. Biol. Univ. Genova 2004, 68, 391-397.

44. Gunasekera, S.P.; Cross, S.S. Fistularin-3 and 11-ketofistularin-3. Feline leukemia virus active bromotyrosine metabolites from the marine sponge Aplysina archeri. J. Nat. Prod. 1992, 55, 509-512. [CrossRef] [PubMed]

45. Sharma, G.M.; Burkholder, P.R. Studies on the antimicrobial substances of sponges II. Structure and synthesis of a bromine-containing antibacterial, compound from a marine sponge. Tetrahedron Lett. 1967, 8, 4147-4150. [CrossRef]

46. Debitus, C.; Guella, G.; Mancini, I.; Waikedre, J.; Guemas, J.P.; Nicolas, J.L.; Pietra, F. Quinolones from a bacterium and tyrosine metabolites from its host sponge, Suberea creba from the Coral Sea. J. Mar. Biotechnol. 1998, 6, 136-141. [PubMed]

47. Weiss, B.; Ebel, R.; Elbrächter, M.; Kirchner, M.; Proksch, P. Defense metabolites from the marine sponge Verongia aerophoba. Biochem. Syst. Ecol. 1996, 24, 1-7. [CrossRef]

48. Shaala, L.A.; Khalifa, S.I.; Mesbah, M.K.; van Soest, R.W.M.; Youssef, D.T.A. Subereaphenol A, a new cytotoxic and antimicrobial dibrominated phenol from the Red Sea sponge Suberea mollis. Nat. Prod. Commun. 2008, 3, 219-222. [CrossRef]

49. D'Ambrosio, M.; Gueriero, A.; Pietra, F. Novel, racemic or nearly-racemic antibacterial bromo- and chloroquinols and $\gamma$-lactams of the verongiaquinol and the cavernicolin type from the marine sponge Aplysina (=Verongia) cavernicola. HeIv. Chim. Acta 1984, 67, 1484-1492. [CrossRef]

50. Shaala, L.A.; Almohammadi, A. Biologically active compounds form the Red Sea sponge Suberea sp. Pak. J. Pharm. Sci. 2017, 30, 2389-2392.

51. Thomas, C.; Wolff, W.; Padmakumar, K.; Ebel, R.; Proksch, P.Z. Chemical defense of Mediterranean sponges Aplysina cavernicola and Aplysina aerophoba. Z. Naturforsch. 2004, 59c, 113-122. [CrossRef]

52. Fattorusso, E.; Minale, L.; Sodano, G. Aeroplysinin-1, an antibacterial bromo-compound from the sponge Verongia aerophoba. Chem. Soc. Perkin Trans. 1972, 1, 16-18. [CrossRef]

53. Fulmor, W.; Van Lear, G.E.; Morton, G.O.; Mills, R.D. Isolation and absolute configuration of the aeroplysinin I enantiomorphic pair from Ianthella ardis. Tetrahedron Lett. 1970, 11, 4551-4552. [CrossRef]

54. Teeyapant, R.; Woerdenbag, H.J.; Kreis, P.; Hacker, J.; Wray, V.; Witte, L.; Proksch, P. Antibiotic and cytotoxic activity of brominated compounds from the marine sponge Verongia aerophoba. Z. Naturforsch. 1993, 48, 939-945. [CrossRef]

55. Koulman, A.; Proksch, P.; Ebel, R.; Beekman, A.C.; van Uden, W.; Konings, A.W.; Pedersen, J.A.; Pras, N.; Woerdenbag, H.J. Cytoxicity and mode of action of aeroplysinin-1 and a related dienone from the sponge Aplysina aerophoba. J. Nat. Prod. 1996, 59, 591-594. [CrossRef] [PubMed]

56. Kreuter, M.H.; Leake, R.E.; Rinaldi, F.; Müller-Klieser, W.; Maidhof, A.; Müller, W.E.G.; Schröder, H.C. Inhibition of intrinsic protein tyrosine kinase activity of EGF-receptor kinase complex from human breast cancer cells by the marine sponge metabolite (+)-aeroplysinin-1. Comp. Biochem. Physiol. B Biochem. Mol. Biol. 1990, 97, 151-158. [CrossRef] 
57. Martinez-Poveda, B.; Garcia-Vilas, J.A.; Cardenas, C.; Melgarejo, E.; Quesada, A.R.; Medina, M.A. The brominated compound aeroplysinin-1 inhibits proliferation and the expression of key pro-inflammatory molecules in human endothelial and monocyte cells. PLOS ONE 2013, 8, 1-8. [CrossRef] [PubMed]

58. Hinterdinga, K.; Knebelb, A.; Herrlichb, P.; Waldmanna, H. Synthesis and biological evaluation of aeroplysinin analogues: A new class of receptor tyrosine kinase inhibitors. Bioorg. Med. Chem. 1998, 6, 1153-1162. [CrossRef]

59. Abou-Ashour, M.I.; Shaala, L.A.; Youssef, D.T.A.; Bader, J.M.; Habib, A.M. Bioactive brominated metabolites from the Red Sea sponge Suberea mollis. J. Nat. Prod. 2008, 71, 1464-1467. [CrossRef] [PubMed]

60. Buchanan, M.S.; Carroll, A.R.; Wessling, D.; Jobling, M.; Avery, V.M.; Davis, R.A.; Feng, Y.; Xue, Y.; Oster, L.; Fex, T.; et al. Clavatadine A, a natural product with selective recognition and irreversible inhibition of factor Xia. J. Med. Chem. 2008, 51, 3583-3587. [CrossRef] [PubMed]

61. Buchanan, M.S.; Carroll, A.R.; Wessling, D.; Jobling, M.; Avery, V.M.; Davis, R.A.; Feng, Y.; Hooper, J.N.A.; Quinn, R.J. Clavatadines C-E, guanidine alkaloids from the Australian sponge Suberea clavata. J. Nat. Prod. 2009, 72, 973-975. [CrossRef] [PubMed]

62. Mani, L.; Jullian, V.; Mourkazel, B.; Valentin, A.; Dubois, J.; Cresteil, T.; Folcher, E.; Hooper, J.N.A.; Erpenbeck, D.; Aalbersberg, W.; et al. New antiplasmodial bromotyrosine derivatives from Suberea ianthelliformis (Lendenfeld, 1888). Chem. Biodivers. 2012, 9, 1436-1451. [CrossRef] [PubMed]

63. Lee, Y.J.; Han, S.; Lee, H.S.; Kang, J.S.; Yun, J.; Sim, C.J.; Shin, H.J.; Le, J.S. Cytotoxic psammaplysin analogues from a Suberea sp. marine sponge and the role of the spirooxepinisoxazoline in their activity. J. Nat. Prod. 2013, 76, 1731-1736. [CrossRef] [PubMed]

64. El-Demerdash, A.; Moriou, C.; Toullec, J.; Besson, M.; Soulet, S.; Schmitt, N.; Petek, S.; Lecchini, D.; Debitus, C.; Al-Mourabit, A. Bioactive bromotyrosine-derived alkaloids from the Polynesian sponge Suberea ianthelliformis. Mar. Drugs 2018, 16, 146. [CrossRef] [PubMed]

65. Bowden, B.F.; McCool, B.J.; Willis, R.H. Lihouidine, a novel spiro polycyclic aromatic alkaloids from the marine sponge Suberea n. sp. (Aplysinellidae, Verongida). J. Org. Chem. 2004, 69, 7791-7793. [CrossRef]

66. Carroll, J.; Jonsson, E.N.; Ebel, R.; Hartman, M.S.; Holman, T.R.; Crews, P. Probing sponge-derived terpenoids for human 15-lipoxgenase inhibitors. J. Org. Chem. 2001, 66, 6847-6851. [CrossRef]

67. Lee, J.; Shin, A.Y.; Lee, H.S. Isolation and synthesis of luffariellolide derivatives and evaluation of antibacterial activities against Gram-Negative bacteria. Bull. Korean Chem. Soc. 2017, 38, 804-807. [CrossRef]

68. Carletti, I.; Massiot, G. Macrolides Useful as Anticancer Agents. U.S. Patent WO2014114729 A1, 31 December 2015. Available online: https://patents.google.com/patent/US20150376222A1/en (accessed on 9 January 2019).

69. Carletti, I.; Massiot, G. Macrolides Useful as Anticancer Agents. U.S. Patent US9873715B2, 23 January 2018. Available online: https:/ / patents.google.com/patent/US9873715B2/en (accessed on 9 January 2019).

70. Shimizu, Y. Paralytic shellfish poisons. Prog. Chem. Org. Nat. Prod. 1984, 45, 235.

71. Butler, A.; Walker, J.V. Marine haloperoxidases. Chem. Rev. 1993, 93, 1937. [CrossRef]

72. Mani, L. The isolation and characterization of antibacterial compounds from the marine sponge, Suberea clavata. Master's Thesis, University of the South Pacific, Suva, Fiji, 14 June 2005.

(C) 2019 by the authors. Licensee MDPI, Basel, Switzerland. This article is an open access article distributed under the terms and conditions of the Creative Commons Attribution (CC BY) license (http://creativecommons.org/licenses/by/4.0/). 